\title{
COMPARATIVE ANALYSIS OF LEARNING SPEED AND ACCURACY MOVEMENTS FOR HEALTHY PERSONS AND PERSONS WITH MULTIPLE SCLEROSIS
}

\author{
Dalia Mickevičienė, Neringa Švedaitė, Albertas Skurvydas, Diana Karanauskienė, \\ Mantas Mickevičius, Daiva Ruseckienė \\ Lithuanian Academy of Physical Education, Kaunas, Lithuania
}

\begin{abstract}
Research background and hypothesis. Probability learning theory suggests that repeating the same movements many times we learn the way the movement is performed with some degree of probability. We suppose that persons with multiple sclerosis learn speed and accuracy movements slower than healthy persons.

Research aim was to establish and compare the learning peculiarities of speed and accuracy movements for healthy persons and persons with multiple sclerosis performing a task - five sets of 20 repetitions.

Research methods. The sample of the research included 12 healthy persons and 10 persons with multiple sclerosis. The study was conducted using Dynamic Parameter Analyzer DPA-1 for arm and leg movements.

Research results showed that multiple sclerosis had a significant effect $(\mathrm{p}<0.05)$ on the average speed of movement (Va), maximal speed of movement ( Vm), time to maximal speed (TVm), and time to target (Tv).

Discussion and conclusions. Learning effect occurred in the course of the whole task, and it was the same for both persons with multiple sclerosis and healthy persons. Research results showed that learning dynamics was almost the same for persons with multiple sclerosis and healthy persons, but the indices of MS persons were worse, i. e. they performed movements slower and with greater variability compared to healthy persons.
\end{abstract}

Keywords: reaction time, manual task, complexity of the task, movement learning.

\section{INTRODUCTION}

$\mathrm{I}$ n healthy myelin, our movements are not impaired, they are fast and accurate. When the layer of myelin is damaged, the spread of nervous impulse is distorted or broken. Scars occur in the place of distorted myelin, and this is called sclerosis (Zheng et al., 2003).

Multiple sclerosis is a demyelinising disease of the central nervous system which damages the brain and the spinal cord. It is a chronic demyelinising disease. The real causes of this disease are not known (Malciene, 2004). Pathogenesis of this disease is not exactly known, either. This disease is thought to be autoimmune (Halpern et al., 2011). MS is a hardly predictable disease. Its symptoms as well as the disease itself are absolutely individual. The symptoms depend on the place in the central nervous system which is affected by the disease.
A motor skill is the ability to plan and implement the aim of the movement - a task (Skurvydas, 2008). There are three stages of movement skill development - cognitive, associative and automation. During those stages certain functional and structural changes occur in some areas of the cerebral cortex, basal ganglion, and cerebellum (Karni et al., 1998).

Research hypothesis: learning speed and accuracy movements of persons with multiple sclerosis is slower than that of healthy persons.

Research aim was to establish and compare the learning peculiarities of speed and accuracy movements for healthy persons and persons with multiple sclerosis performing a task - five sets of 20 repetitions. 


\section{RESEARCH METHODS}

The research was carried out following the principles of the Declaration of Helsinki about the ethics of experimentation with humans. The study was conducted in the LAPE Laboratory of Human Motoric using Dynamic Parameter Analyzer DPA1 for arm and leg movements.

The sample of the research included 22 subjects. Ten of them were with multiple sclerosis they and made up a research group regardless of the form of the disease. Persons with multiple sclerosis (MS) had been ill with this disease for $13.8 \pm 11.3$ years. Their age was $42 \pm 10.5$ years, height $173.1 \pm$ $7.7 \mathrm{~cm}$, and weight $74.1 \pm 15.5 \mathrm{~kg}$. The control group consisted of 12 healthy persons aged $44.3 \pm$ 1.4 years, height $167.2 \pm 4 \mathrm{~cm}$, and weight $79.1 \pm$ $4.2 \mathrm{~kg}$. The patients volunteered to participate in the research after they were acquainted with the research aims, procedures and the course.

DPA-1 is a device which allows researching reaction time, dynamic (strength, power) and kinematic (range of movement, speed, acceleration) characteristics of movements.

During the research the subjects sat in a special chair at the table with DPA-1 fastened on it. The back of the subject was straight, resting on the chair back, both arms were flexed at the elbow joint at the angle of $90^{\circ}$ so that the upper arms were at the sides of the body and the forearms were leaning of the support panel. The position of DPA-1 chair was regulated so that the subject could sit comfortably in a standard position. The distance between the computer screen and the eyes was $\sim 0.7 \mathrm{~m}$.

The subjects performed the task with their right hand. According to the task prepared beforehand, the target (a red circle $0.007 \mathrm{~m}$ in width) appeared on the screen at the determined time. The distance between the start zone and the target was $0.16 \mathrm{~m}$. The path of arm movement was identically repeated on the computer screen. During each task the subject set the handle symbol, $0.0035 \mathrm{~m}$ wide, at the start zone on the computer screen (the center of a green circle $0.01 \mathrm{~m}$ wide). The programme generated an audible signal everyl-3 seconds, and at the same time the subject had to react and to push the handle so that he/she could hit the target. The cycle of measurement ended when the handle symbol hit the target. Information about the task performed was stored on the computer and later moved to Microsoft Excel programme.

The complicated task was performed. The subject had to react to a target appearing on a computer screen and push the handle so that the symbol circle reached the target and stopped in it as fast as possible and in the most exact movement trajectory. The target appeared on the computer screen in the same place all the time. The end moment of movement was recorded when the center of the handle symbol stopped in the circle and remained in it no shorter than $0.03 \mathrm{~s}$. After the task was explained the subjects were allowed three trials, the results of which were not recorded. Then the subjects performed five sets of tasks with 20 repetitions in each. The rest interval between the sets of repetitions was $2 \mathrm{~min}$, and the repetitions of one set were performed without stopping, and we registered the maximal and the average speed of movement, reaction time and the path of movement for the right hand. After each repetition the subjects saw their result on the computer screen. They were encouraged to perform the task as fast and as accurately as possible.

The data analysis was performed using SPSS 17.0 programme package. The data were processed calculating the mean values of the researched indices $(\bar{x})$, mean standard deviation (s), coefficient of variance (VA\%), Pearson's correlation coefficient (r). The significance of results of different factors was assessed using two-factor analysis of variance. The significance of difference was set at $\mathrm{p}<0.05$.

\section{RESEARCH RESULTS}

The analysis of the research results showed that comparing MS persons and healthy persons statistically significant differences were found in the following registered indices: time to target (Figure 1), average speed (Figure 2), maximal speed (Figure 3), and time to maximal speed (Figure 4).

Research results showed that disease had a significant effect on the average speed of movement $(p<0.05)$, maximal speed of movement $(p<0.05)$, time to maximal speed $(\mathrm{p}<0.05)$, and time to target $(\mathrm{p}<0.05)$.

Research results indicated that learning dynamics of MS patients and healthy persons was almost the same, but the indices of MS patients were worse, i. e. they performed everything slower than healthy persons. The interaction between the groups (MS patients and healthy persons) and repeated trials was statistically significant, i. e. learning dynamics of the average speed of movement $(\mathrm{p}<0.05)$, maximal speed of movement $(\mathrm{p}<0.05)$, time to maximal speed $(\mathrm{p}<0.05)$, and time to target $(p<0.05)$ was different. Learning 
Figure 1. Mean values of time to target (s) for MS persons and healthy persons performing the task five sets with 20 repetitions in each set

Note. * $-p<0.05$, comparing MS persons with healthy persons.

Figure 2. Mean values of average speed ( $\mathrm{mm} / \mathrm{s})$ for MS persons and healthy persons performing the task five sets with 20 repetitions in each set

Note. ${ }^{*}-\mathrm{p}<0.05$, comparing MS persons with healthy persons.

Figure 3. Mean values of maximal speed $(\mathrm{mm} / \mathrm{s})$ for MS persons and healthy persons performing the task - five sets with 20 repetitions in each set

Note. ${ }^{*}-\mathrm{p}<0.05$, comparing MS persons with healthy persons.
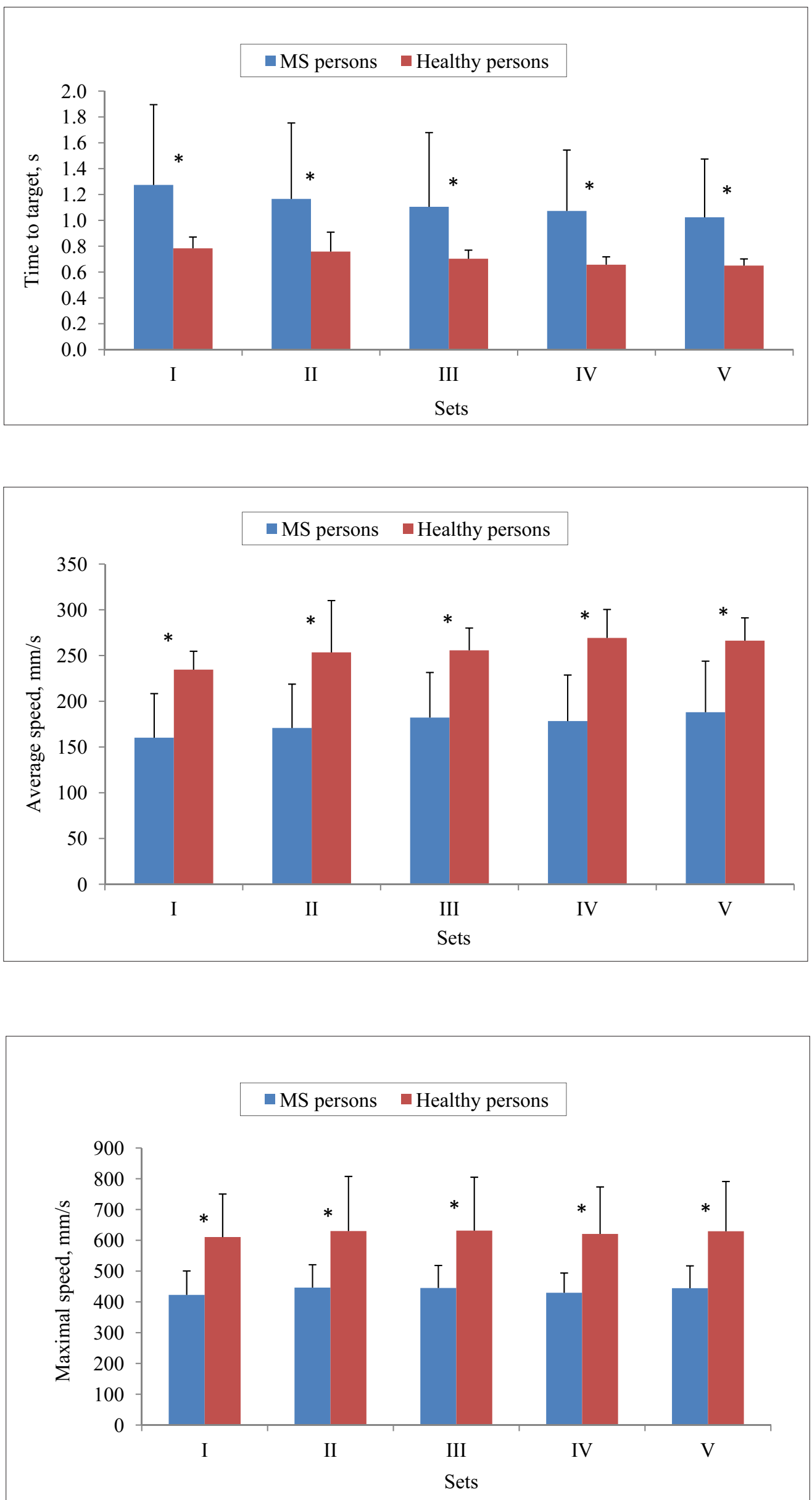


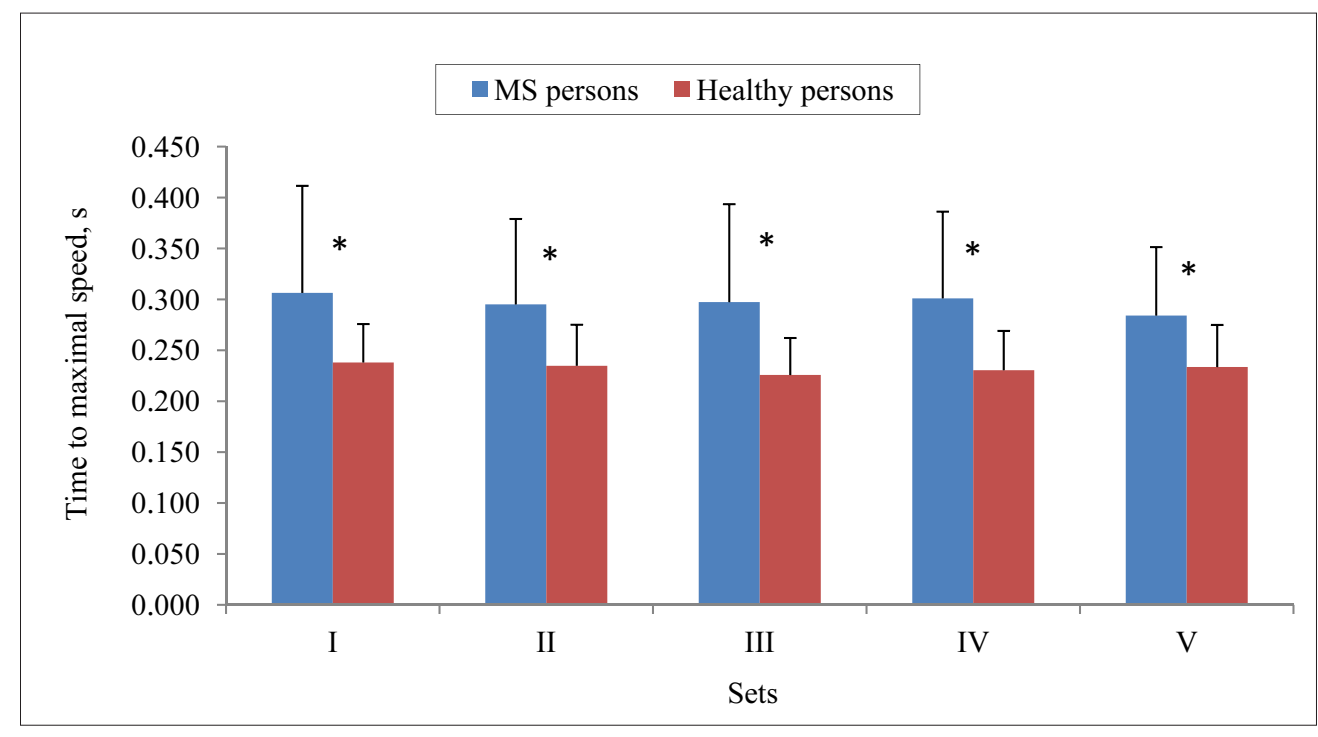

\begin{tabular}{|c|c|c|c|c|c|c|c|c|c|c|c|c|}
\hline Indices & \multicolumn{2}{|c|}{$\begin{array}{c}\text { Reaction time, } \\
\text { \% }\end{array}$} & \multicolumn{2}{|c|}{$\begin{array}{c}\text { Time to target, } \\
\text { \% }\end{array}$} & \multicolumn{2}{|c|}{$\begin{array}{c}\text { Average speed, } \\
\%\end{array}$} & \multicolumn{2}{|c|}{$\begin{array}{c}\text { Maximal } \\
\text { speed, \% }\end{array}$} & \multicolumn{2}{|c|}{$\begin{array}{c}\text { Time to } \\
\text { maximal } \\
\text { speed, \% }\end{array}$} & \multicolumn{2}{|c|}{$\begin{array}{c}\text { Path of } \\
\text { movement }\end{array}$} \\
\hline Sets & MS & H & MS & H & MS & H & MS & H & MS & H & MS & H \\
\hline 1 & 24.8 & 9.1 & 44.9 & 11.1 & 30.6 & 8.5 & 18.9 & 22.8 & 33.7 & 15.8 & 7.2 & 7.9 \\
\hline 2 & 27.5 & 9.9 & 49.6 & 19.7 & 28.2 & 22.3 & 16.6 & 28.1 & 27.8 & 17.1 & 13.1 & 6.6 \\
\hline 3 & 27.5 & 7.8 & 43.9 & 9.4 & 27.3 & 9.5 & 16.1 & 27.4 & 31.3 & 16.1 & 10.4 & 5.3 \\
\hline 4 & 20.2 & 9.1 & 42.1 & 9.2 & 31.6 & 11.5 & 22.4 & 24.6 & 28.3 & 16.7 & 18.6 & 5.1 \\
\hline 5 & 20.6 & 7.8 & 40.6 & 7.9 & 29.6 & 9.3 & 17.1 & 25.6 & 22.7 & 17.6 & 7.1 & 3.5 \\
\hline
\end{tabular}

Figure 4. Mean values of time to maximal speed (s) for MS persons and healthy persons performing the task - five sets with 20 repetitions in each set
Note. $*-p<0.05$, comparing MS persons with healthy persons. effect was observed during the whole task, and it was the same to both MS patients and healthy persons.

Aiming at evaluating the dispersion of our researched indices we calculated the coefficients of variance of indices in different tasks. The research showed that MS persons performed the tasks with greater variability compared to healthy persons. The highest coefficients of variance for MS persons were observed in the indices of time to target (40.6-49.6\%) and time to maximal speed (22.7-33.7\%). The highest coefficients of variance for healthy persons were observed in the indices of maximal speed (22.8-28.1\%).

\section{DISCUSSION}

As far as we know, this is the first research analyzing speed and accuracy movement learning for patients with multiple sclerosis.

The aim of this study was to establish differences in learning speed and accuracy movements for persons with multiple sclerosis and healthy persons. The main conclusion obtained was that persons with multiple sclerosis performed movements slower and with greater variability, though their accuracy did not differ from that of healthy persons.

Movement learning depends on two different processes - fast and slow learning. Fast learning process is characterized by fast learning and fast forgetting. Slow learning process is characterized by slow learning and slow forgetting (Ethier et al., 2008). In speed and accuracy tasks, children's accuracy improves at the expense of their speed, but for adults only the average speed of movement increases (Motiejūnaitè et al., 2011). In this research the results in both groups improved, and the accuracy did not decrease in either group.

Researchers claim that it is difficult to reconcile the speed and accuracy of movements because when the movement is performed fast, its duration decreases, thus the possibilities of its correction decrease as well (Schmidt, Lee, 1999). D. Mickevičienè et al. (2008) suggest that the more complicated the task, the slower the reaction and the maximal speed of movement, compared to a simple task. But it does not mean that the speed of 
movement would be greater while reacting faster to a simple stimulus. All those findings confirm Hick's law stating that reaction time is directly proportional to the complexity of movement (complexity of the task).

Researchers suggest that there is no significant difference between reaction time results when performing the task with the right and the left hand. There is also no significant difference between genders. Though there is no significant difference if the task is performed by a woman or a man, but research results show that women's reaction time is slower than that of men. Both women and men reach faster and more accurately when performing a task with their right hand, but as their left hand is concerned, their reaction is rather more accurate than faster (Motiejūnaite et al., 2010). A. Zuoza et al. (2009) studied the performance of speed and accuracy movements with the left hand, contrary to this research. Their findings show that the left hand is less accurate than the right hand, but the target is reached rather fast. The left hand can develop greater strength and power comparing it with the right hand.

One of the most interesting studies was carried out by A. Skurvydas et al. (2009) where they studied the dependence of movement speed on the body mass. The main conclusion obtained by the authors was that the greater the body mass, the slower the reaction time.

Dispersion of variance is considered low when the coefficient of variance is from 0 to $10 \%$, average - from 10 to $20 \%$, and high - more than 20\% (Gonestas, Strielčiūnas, 2003). Our results showed that MS patients performed speed and accuracy movements with high variability, but the accuracy of movement did not suffer from that and it did not differ from that of healthy persons. Movement variability is the greatest in the first stage and the least in the automation stage. It was observed that moving to the second stage (associative or perception) movement variability could increase (Liu et al., 2006). In our research movement variability steadily declined in both groups.

Research results showed that comparing the coefficients of variance of the registered indices for MS patients and healthy persons we could claim that dispersion of variance of all indices for MS patients was greater compared to healthy adult persons.

Summing up, we suggest that for both healthy and MS persons, movement accuracy improved at the expense of speed, the average of the mean speed improved, and the time to target became shorter. The majority of the registered indices significantly changed for both groups of subjects. We suppose that in the process of fast learning MS persons tend to alter the variables of their movements more than healthy persons. We suggest that feedback and the mechanism of the correction of mistakes as internal models of fast learning alter more among MS persons that healthy persons.

\section{CONCLUSIONS AND PERSPECTIVES}

1. Persons with multiple sclerosis performed speed and accuracy movements slower and with greater variability, though their accuracy did not differ from that of healthy persons.

2. The duration of planning movement of persons with multiple sclerosis, which is indicated by reaction time, was significantly longer than that of healthy persons.

3. Dynamics of movement learning did not differ for persons with multiple sclerosis and healthy persons.

\section{REFERENCES}

Ethier, V., Ze, D. S., Shadmehr, R. (2008). Spontaneous recovery of motor memory during saccade adaptation. Journal of Neurophysiology, 99 (5), 2577-2583.

Gonestas, E., Strielčiūnas, M. (2003). Taikomoji statistika: vadovèlis kūno kultūros ir sporto specialybiu studentams (bakalaurams, magistrantams) bei doktorantams. Kaunas: LKKA.

Halpern, R., Agarwal, S., Dembek, C., Borton, L., Lopez-Bresnahan, M. (2011). Comparison of adherence and persistence among multiple sclerosis patients treated with disease modifying therapies: A retrospective administrative claims analysis. Patient Preference and Adherence, 5, 73-84.

Karni, A., Meyer, G., Jezzard, P. et al. (1998). Functional MRI evidence for adult motor cortex plasticity during motor skill learning. Nature, 14, 377 (6545), 155-158.

Liu, Y. T., Mayer-Kress, G., Newell, K. M. (2006). Qualitative and quantitative change in the dynamics of motor learning. Journal of Experimental Psychology: Human Perception and Performance, 32 (2), 380-393. 
Malcienè, L. (2004). Išsétinè sklerozé: epidemiologija ir sergančiuju gyvenimo kokybé Kauno mieste: daktaro disertacija. Kaunas.

Mickevičienè, D., Motiejūnaitè, K., Skurvydas, A. et al. (2008). How do reaction time and movement speed depend on the complexity of the task? Ugdymas. Küno kultūra. Sportas, 2 (69), 57.

Motiejūnaitė, K., Mickevičienè, D., Skurvydas, A., Karanauskienè, D., Mickevičius, M. (2010). Does performance of speed- accuracy movement depend of gender and the left or the right hand? Ugdymas. Küno kultūra. Sportas, 2 (77), $63-68$.

Motiejūnaitè, K., Mickevičienè, D., Skurvydas, A. et al. (2011). Time of fast learning in speed - accuracy tasks is different for children and adults. Ugdymas. Küno kultūra. Sportas, 1 (80), 49-55.
Schmidt, R. A., Lee, T. D. (1999). Motor Control and Learning: A Behavioral Emphasis. Champaign, Illinois: Human Kinetics.

Skurvydas, A., Gutnic, B., Zuoza, A., K. et al. (2009). Relationship between simple reaction time and body mass index. Journal of Comparative Human Biology, 1 (60), 77-85.

Skurvydas, A. (2008). Judesiu mokslas: raumenys, valdymas, mokymas, reabilitavimas, sveikatinimas, treniravimas, metodologija. Kaunas: LKKA.

Zheng, B., Ho, C., Li, S. et al. (2003). Lack of enhanced spinal regeneration in Nogo deficient mice. Neuron, 24, 38 (2), 213-224.

Zuoza, A. K., Skurvydas, A., Mickevičienè, D. et al. (2009). Behavior of dominant and non dominant arms during ballistic protractive target - directed movements. Human Physiology, 3 (35), 576-584.

\title{
SVEIKŲ IR SERGANČIŲJŲ IŠSĖTINE SKLEROZE GREITŲ BEI TIKSLIŲ JUDESIŲ MOKYMOSI LYGINAMOJI ANALIZE்
}

\author{
Dalia Mickevičienė, Neringa Švedaitė, Albertas Skurvydas, Diana Karanauskienė, \\ Mantas Mickevičius, Daiva Ruseckienė \\ Lietuvos kūno kultūros akademija, Kaunas, Lietuva
}

\begin{abstract}
SANTRAUKA
Tyrimo pagrindimas ir hipotezé. Anot tikimybinès išmokimo teorijos, daug kartų kartojant tuos pačius judesius galima greičiau ir tiksliau juos atlikti. Manoma, kad sergančiujų išsėtine skleroze (IS) greitų ir tikslių judesių mokymasis yra lètesnis nei sveikų asmenų.

Tikslas - nustatyti bei palyginti sveikų asmenų ir sergančiujų IS greitų bei tikslių judesių mokymosi ypatumus atliekant užduoti - 5 serijas po 20 kartojimų.

Metodai. Tiriamają grupę sudarė 12 sveikų asmenų ir 10 sergančiujų IS. Tyrimas atliktas naudojant žmogaus rankų ir kojų judesių dinaminių parametrų analizatorių DPA-1.

Rezultatai. Sergančiujuc IS vidutinio judesio greičio (Va), maksimaliojo judesio greičio (Vm), laiko iki maksimaliojo greičio $(\mathrm{TVm})$ ir laiko iki taikinio (Tv) rodikliai buvo prastesni nei sveikų tiriamujų ir reikšmingai skyrèsi $(\mathrm{p}<0,05)$.

Aptarimas ir išvados. Mokymosi efektas buvo pastebimas visos užduoties metu ir pasireiškè vienodai tiek tarp sergančiujų IS, tiek tarp sveikų tiriamujų. Tyrimo rezultatai parodė, kad sergančiujų IS ir sveikų asmenų mokymosi kaita yra beveik tokia pati, tačiau sergančiujų rodikliai yra prastesni, t. y. jie viską atlieka lečriau ir kaičiau nei sveiki asmenys.
\end{abstract}

Raktažodžiai: reakcijos laikas, užduotis rankoms, užduoties sudètingumas, judesių mokymasis.

Gauta 2012 m. sausio 6 d.

Received on January 6, 2012

Priimta $2012 \mathrm{~m}$. kovo $13 \mathrm{~d}$.

Accepted on March 13, 2012
Corresponding author Dalia Mickevičienė Lithuanian Academy of Physical Education Sporto str. 6, LT - 44221 Kaunas Lithuania

Tel +37061758513

E-mail d.mickeviciene@lkka.lt 